\title{
Conceptions of Language Input in Second Language Acquisition: A Case of Vietnamese EFL Teachers
}

\author{
Nguyen Van Loi \\ Can Tho University \\ loinguyen@ctu.edu.vn \\ Margaret Franken \\ University of Waikato \\ Franken@waikato.ac.nz
}

\begin{abstract}
The importance of incorporating second language acquisition (SLA) research into second language teacher education and classroom practice has been recognised (Ellis, 2005; Tarone \& Allwright, 2005). However, this is a challenge as exemplified in task-based language teaching (TBLT), which closely draws on SLA research. The present study focuses specifically on one area of SLA, language input. By using a multimethod case study approach, it documents six Vietnamese EFL teachers' conceptions of input. The study generally showed that the teachers had a synthetic conception of input. Some contextual factors also constrained their provision of rich comprehensible input. The study provides insights into how teacher cognition is mediated by professional development, prior teaching experiences, and many other aspects of both present and past contexts (Borg, 2006). Specifically, the study justifies why integrating key SLA concepts into practice is challenging, and why teachers' conceptions must be considered in implementing innovations.
\end{abstract}

Although task-based language teaching (TBLT) is strongly claimed to be a powerful approach because it aligns with how learners acquire a second language (Shehadeh, 2005), research has documented not insignificant obstacles to its implementation in Asian settings (Littlewood, 2007; Swan, 2005). This highlights the concern that externally developed innovations have often disregarded contextual factors. Given the widespread interest in and recognition of the importance of professional development in new and emerging language teaching methods and approaches, it is essential to reconsider possible ways of addressing this concern. Lightbown (2000) suggests that SLA researchers need to listen to what teachers are saying to appreciate their greatest areas of need in professional development and knowledge, and to understand the contexts in which they work. To do this means to understand teachers' conceptions.

The present study approaches teachers' conceptions from a constructivist perspective, seeing teacher learning as the personal specific meanings teachers construe for knowledge, skills, or concepts, which in turn mediate their actions in practice. Teachers' conceptions not only interact with their classroom practice, but also are shaped by their own educational experiences, professional development experiences, prior teaching experiences and many

Language Education in Asia, 2010, 1(1), 62-76. http://dx.doi.org/10.5746/LEiA/10/V1/A06/Nguyen_Franken 
other aspects of both present and past contexts (Borg, 2006). As a result, teachers' conceptions are idiosyncratic, conscious, evolving, and context-specific (Entwistle, Skinner, Entwistle \& Orr, 2000).

Research into language teachers' conceptions is abundant (see Borg, 2006). However, few studies have focused on SLA issues such as classroom input via teachers' use of the target language (e.g. Bateman, 2008, Macaro, 1997; Turnbull \& Arnett, 2002). In the context of Vietnam, research on teachers' cognition is scarce (Canh, 2008), let alone research on teachers' cognition about SLA concepts. Borg (2003) stresses the important need for research into SLA issues particularly in contexts where English is "taught by non-native teachers and where syllabuses are to various degrees prescribed" (p.98).

The study examined ways of working with Vietnamese English teachers specifically in the area of knowledge of language input. Researchers, including Hedge (2000), have suggested there are specific areas from SLA research that deserve special attention from the teacher's perspective; Hedge's list includes the nature of input.

While the term input invokes various conceptions, Chaudron's definition is helpful. He states that, "[t] he input available to second language learners is the raw data from which they derive both meaning and awareness of the rules and structures of the target language" (Chaudron, 1985, p.3). Carroll (1999) notes that conceiving of input as raw data as compared with analyzed data is popular in SLA research. Saleemi (1989) further explains that the concept of input depends on the researcher's resources and interests, and more importantly, his/her view of language.

There are ultimately two ways of viewing language and therefore the input for learners. These views expressed in synthetic and analytic syllabuses. Synthetic syllabuses see language as compartmentalized linguistic pieces that teachers work to present one at a time, and that learners work to master and assemble for use in communication (Wilkins, as cited in Long \& Crookes, 1992). Traditional approaches such as Grammar Translation and Present-PracticeProduce embody this view. Conversely, analytic syllabuses present language as integrated chunks without direct manipulation or selection of discrete structures or lexis. Language is primarily seen as a means of communication rather than a subject matter, and language learning is viewed as a psycholinguistic process rather than a linguistic structure. However, it may be the case in syllabuses of this nature that the input has been "modified in other ways" (Long \& Crookes, 1992, p. 28). In recent years, this analytic approach has been promoted in many Asian countries in an attempt to bring SLA research closer to classroom practice, manifest specifically in task-based instruction. Embedded in such a perspective is the notion of comprehensible input and negotiable input.

Krashen's (1985) comprehensible input implies that learners need to understand the message conveyed to them and have yet to process some linguistic data beyond their existing language competence. The nature of input is therefore important. Modified input, in terms of phonological or syntactic simplifications, lexical elaboration, adaptation of speech rate, or even speech elaboration, is especially useful for lower proficiency learners (Wesche, 1994). A particular type of modified input that has practical relevance to classroom practice is teacher use of the target language in the classroom (Ellis, 1985). Research has pointed out increased comprehension of written and oral texts due to teacher elaborative speech (Wesche, 1994). In addition, purposefully enhanced input containing saliently made linguistic forms can facilitate learners' comprehension and uptake (Ellis, 2003; Harley, 1998). Long's (1981) interaction hypothesis also suggests that negotiation generates comprehensible input as learners actively 
engage in communication; this is useful for language acquisition. Krashen (1985) sums up three useful features of comprehensible input: salience, frequency of occurrence, and relevancy to the learner.

Further, exposure to an extensive amount of input through extensive reading conceivably promotes second language learning, especially general language proficiency (Elley \& Mangubhai, 1983, as cited in Mangubhai, 2006).

Research regarding teachers' concerns in adopting more meaning based or communicative tasks in many Asian countries like Japan, South Korea, China, and Hong Kong (Littlewood, 2007) seems to point out that these concerns may have an impact on teachers' willingness to embrace notions of rich and comprehensible input, and extensive opportunities for negotiated interaction. Teachers can be challenged by the requirement to use English extensively, while seeing that communicative activities and tasks often fail to result in rich language use by the learners.

\section{Context and Participants}

\section{Method}

In Vietnam, English language teaching (ELT) in universities is still focused on linguistic knowledge. Tertiary institutions do not build on school curricula, but tend to develop program packages based on a few selected commercial English textbooks (Trinh, 2005). Teaching largely follows the prescribed textbooks and is subject to a limit of approximately three fortyfive-minute periods per week, and a total of number of periods ranging from 180 to 300 . Classes comprise a large number of students whose proficiency levels are usually mixed. Teaching is also mainly for testing, which often ignores communicative skills. In addition, as in many other Asian countries, the lack of a social environment for communicating in English generally restricts ELT in Vietnam (Canh, 2000). Although training programs include a component about communicative language teaching (CLT), teachers are often constrained from teaching communicatively (Pham, 2005).

The Vietnamese teachers in this study worked in a university whose ELT program ultimately follows what is described above. The ELT program at their university has had a focus on grammar and reading, but recently changed to incorporate basic communicative skills. The program was based on two textbooks divided into five levels from elementary (levels 1-3) to pre-intermediate (levels 4-5); each textbook has ten units. The university has approximately 21,000 students (www.ctu.edu.vn), and classes on average have 50 students. Information about the participants (with pseudonyms) is given in Table 1.

\section{Table 1}

Profiles of Six EFL Vietnamese Teachers

\begin{tabular}{|l|l|l|c|l|l|c|}
\hline Teacher & Age & Gender & $\begin{array}{c}\text { Years of } \\
\text { service }\end{array}$ & \multicolumn{1}{|c|}{ Qualifications } & \multicolumn{1}{|c|}{ Status } & $\begin{array}{c}\text { Classes } \\
\text { taught }\end{array}$ \\
\hline Kim & 35 & Female & 12 & BA in TEFL; MA in TESOL & Lecturer & Level 2 \\
\hline Hoa & 34 & Female & 11 & BA in TEFL; MA in American Studies & Lecturer & Level 3 \\
\hline My & 29 & Female & 6 & $\begin{array}{l}\text { BA in TEFL; MA in Educational } \\
\text { Studies }\end{array}$ & Lecturer & Level 1 \\
\hline Phuc & 26 & Female & 4 & BA in TEFL & Lecturer & Level 2 \\
\hline Thu & 24 & Female & 3 & BA in TEFL & Lecturer & Level 3 \\
\hline Sinh & 22 & Female & 0.5 & BA in TEFL & $\begin{array}{l}\text { Apprentice } \\
\text { lecturer }\end{array}$ & Level 2 \\
\hline
\end{tabular}




\section{Procedure}

The present study is derived from a larger study which aimed to examine teachers' responses to the knowledge of essential conditions for SLA that we have termed facilitating conditions (see Doughty \& Long, 2003). One of the facilitating conditions, language input, was introduced to the participants in a two-hour workshop focusing on the concept and nature of input as outlined above. The workshop aimed to elicit the teachers' thinking about the idea of enriching language input in their English classrooms. The key idea proposed in the workshop was that teachers "try out some of the pedagogical applications suggested by SLA research [to] understand what it really means for their own teaching context" (Lightbown, 2000, p. 453).

Data were collected in September 2007. Before the workshop, interviews were conducted to stimulate the participants to talk about their understanding of the SLA facilitating conditions: one group interview with four participants, and two individual interviews with the others. After the workshop, the teachers planned their own lessons in which they explored and sought to exploit the concept of input. They presented lesson plans, and were interviewed to clarify their plans. After teaching their lessons, they wrote reflections, and then were engaged in stimulated recall sessions, where they talked about moments in their lessons, elaborating on their aims, intentions, and evaluations of what they were doing at the time. (See Appendix A for question prompts used at each of these interview occasions.)

The study triangulated all the sources of data: three initial interviews (one group and two individual), six lesson plans, six lesson plan interviews, six reflective writings, and six stimulated recall sessions. Interpretation also followed the process of corroborating the different data (Denzin, 1988). Due to limited space, this paper selectively presents the data from initial interviews, lesson plans, reflections, and stimulated recalls.

\section{Findings}

\section{Teachers' Initial Notions of Input}

Table 2 below shows the dimensions of defining input derived from the initial interviews. The data showed that a synthetic notion of input was dominant among the teachers, although some had a broad view. Only Kim, the most experienced teacher, had an understanding of input as language data from the environment. This paper focuses on the dominant feature.

\section{Table 2}

\section{Three Dimensions in Teachers' Defining of Input}

\begin{tabular}{|l|c|c|c|}
\hline \multirow{2}{*}{ Teachers } & \multicolumn{3}{|c|}{ Dimensions of defining input } \\
\cline { 2 - 4 } & $\begin{array}{c}\text { Language } \\
\text { data }\end{array}$ & $\begin{array}{c}\text { Discrete } \\
\text { linguistic elements }\end{array}$ & $\begin{array}{c}\text { Other } \\
\text { knowledge }\end{array}$ \\
\hline Kim & $\sqrt{ }$ & $\sqrt{ }$ & \\
\hline Hoa & & $\sqrt{ }$ & $\sqrt{ }$ \\
\hline My & & $\sqrt{ }$ & \\
\hline Phuc & & $\sqrt{ }$ \\
\hline Thu & & $\sqrt{ }$ & \\
\hline Sinh & & & \\
\hline
\end{tabular}

The following extract from a teacher interview illustrates the dominant understanding of input as discrete linguistic elements.

To address the language input in my class, I give my students some drills so that they can kind of practise and practise the same structure, for example about tense or so, but a lot of drills. (Hoa) 
Concerning the nature of input, Table 3 below shows the five features perceived by the teachers as characterizing good language input. Two teachers (Hoa and Thu) showed a richer understanding than the others did, as they named more characteristics of quality input. Hoa named four aspects, and Thu named three. The most dominant aspect was that they all identified appropriateness to learners' levels as one of the necessary features of language input. For example, one teacher understood that good input should cater for learners' needs. She said depending on learners' levels, the teacher could decide how to provide appropriate input.

...if you are teaching English for a child, and then the language that you pick out to teach a child is very different from the students whose major area is mathematics or science...(Kim)

\section{Table 3}

Conceptions of Good Input Features Across Six Teachers

\begin{tabular}{|l|c|c|c|c|c|}
\hline \multirow{2}{*}{ Teachers } & \multicolumn{5}{|c|}{ Features of good input } \\
\cline { 2 - 6 } & New & Useful & Appropriate & Repeated & Interesting \\
\hline Kim & & & $\sqrt{ }$ & & \\
\hline Hoa & & $\sqrt{ }$ & $\sqrt{ }$ & $\sqrt{ }$ & $\sqrt{ }$ \\
\hline My & & & $\sqrt{ }$ & & \\
\hline Phuc & $\sqrt{ }$ & & $\sqrt{ }$ & $\sqrt{ }$ & \\
\hline Thu & $\sqrt{ }$ & & $\sqrt{ }$ & & \\
\hline Sinh & & & & $\sqrt{ }$ & \\
\hline
\end{tabular}

\section{Accommodating Analytic Input}

In the lesson plans and pre- and post-lesson interviews, it was shown that all the teachers appeared to incorporate the idea of input as the target language addressed to learners for implicit learning. They thought of input as texts, audio, video, or teacher talk. Phuc, for example, chose to simplify an audio-based text to familiarize students with an audio tape they were going to listen to. Likewise, Hoa reported that she regretted not being able to speak English effectively to provide optimal input. It is interesting to note that initially she talked about input in terms of cultural and linguistic knowledge that needed to be taught.

My initially hesitated to articulate her view of the concept, but did show her uptake of the concept in an attempt to apply it in her lesson. This teacher even interpreted input as inclusive of language tasks. When she was prompted in the stimulated recall interview (SRI) on whether rich input had been created for her students' learning, she revealed an analytic conception of input, as indicated below.

I think if talking about the objective of the lesson, it [input] was generally rich. For example, the teacher's instruction was in English, the students listened to the audio tape, and then they practised a situation outside the book, related to their real life. (My-SRI)

While all the teachers showed a degree of understanding input in analytic terms, the data also showed that the teachers accommodated the new concept into their dominant understanding of input as pre-selected linguistic elements. An examination of their lessons and talks about the lessons revealed two dominant themes as discussed below.

A synthetic view as exemplified in lesson objectives and targeted structures. The six participants presented different lesson plans, as summarized in Table B (see Appendix B), but all the lessons expressed a clear emphasis on the predetermined elements of the target 
language directly relevant to the units they taught. Three teachers (Hoa, My, and Sinh) clearly stressed this linguistic objective. Hoa indicated her goal to be the students' ability to use the simple past tense after the lesson. In her reflection, she wrote, "I found the input of the -ed ending very helpful for students." Similarly, My attempted to promote the use of personal information questions in practice. She wrote on her reflective sheet that she had provided all the input necessary for the students to talk about their personal information. Sinh's lesson clearly stressed the grammatical forms relevant to the topic "daily activities." Kim and Thu specified a number of objectives, encompassing the practice of a variety of skills such as listening, reading, and speaking. Close analysis of their lesson activities revealed that they also aimed at specific language items (be going to in Thu's lesson; adverbs of frequency and prepositions of time in Kim's). Thu began with presenting the form and function of the structure, then provided practice of the structure via reading, listening, speaking, and writing. She used drills first, and then provided less controlled speaking and writing tasks called "grammar production," which she said aimed to generate students' input. Kim similarly exploited all the sources of input, namely listening, reading, and speaking, to achieve the linguistic goal specified in her lesson plan. Phuc did not describe any objectives, but her designed activities likewise revealed her intention to teach the modal verb can. She structured the lesson in a way that concentrated students' attention on this verb form and functions through a series of steps - reading, listening, and speaking - to get students to see, hear, and use the structure.

A synthetic view as exemplified in the way input was directed. The linguistic content the teachers intended to teach constituted the focal point to which they directed forms of input. The teachers' recall sessions and reflections on the lessons demonstrate this. Thu, for example, attempted to integrate the different skills in a lesson that sought to teach linguistic content relevant to communicating a topic. Thu presented "be going to," and intentionally repeated it in her talk to give students an opportunity to hear it. Thu commented on her talk in the lesson:

Researcher: What do you think about the language you used at that time?

Thu: $\quad$ There was something old and something new there.

Researcher: What was new?

Thu: $\quad$ It was "going to move, they are going." (Thu-SRI)

Thu further considered pre-teaching new vocabulary as a provision of optimal input, and believed this provision facilitated students' practice and use of the structure in focus.

Any way, they were exposed to reading, speaking, and listening, so they were exposed to that structure. (Thu-SRI, emphasis added)

Likewise, Phuc explained that her attempts to write a text for her students to recognize the functions of can, to get them listening to an audio recording of a native speaker talking about his abilities, and to give students a chance to listen to her and their peers talking about their abilities, all aimed to optimize their exposure to that grammatical form.

I have made it optimal. I have created all the opportunities such as audio, story, my written text for them to recognize the structure. (Phuc-SRI)

\section{The Teachers' Use of English and Constraints}

All the teachers reported their understanding of teachers as a useful source of language input in the classroom. They all thought that teachers' use of English in the classroom was beneficial to students' learning. Nevertheless, they only used English for three purposes: to explain new 
language material, especially when it was concrete, to elicit students to answer questions, and to give simple instructions. This limitation was reflected in their interviews as they spoke about a number of contextual factors. Figure 1 below shows the three dominant factors among the teachers: a concern for comprehension, students' low proficiency, and time pressure.

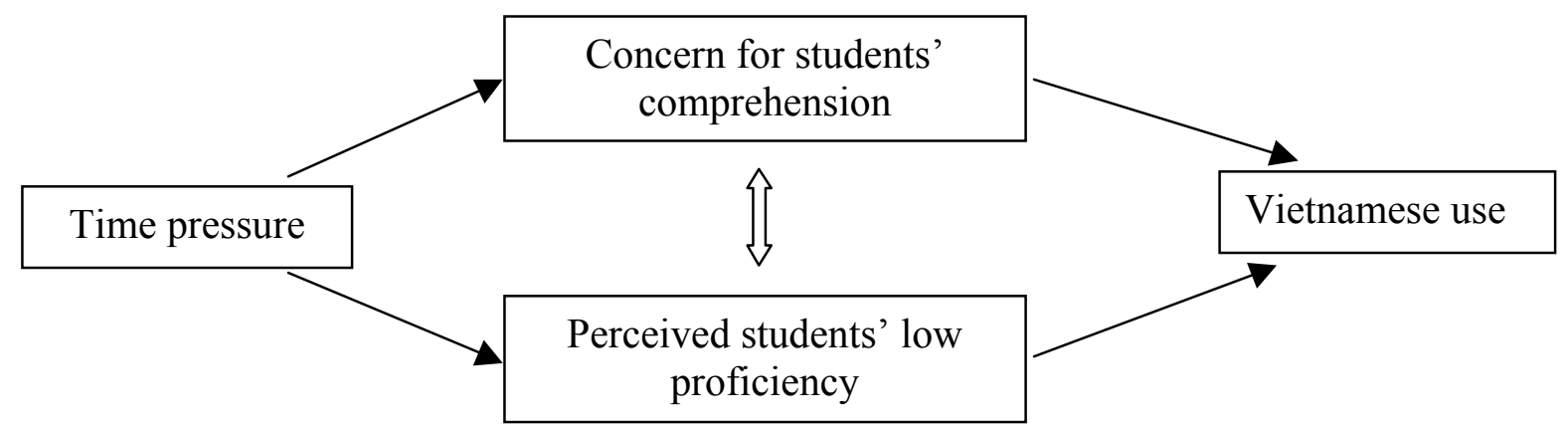

Figure 1. Factors affecting teachers' use of Vietnamese vs. English.

The data, as interpreted in Figure 1 above, shows that the teachers' concern for delivering a comprehensible message to students and their perceptions about the students' ability to comprehend English affected their decision to switch to Vietnamese. Underlying this decision also was the time pressure. For example, Phuc expressed her concern for students' comprehension when she explained a task her students were going to do:

Vietnamese, I spoke English and then Vietnamese because I was afraid they did not understand. I was afraid they did not know the word "line." (Phuc-SRI)

My said she only spoke English when she found it "simpler, less time-consuming, and confusing" than using Vietnamese. The teacher explained further that depending on what she taught, she might use English. Time also mediated this use.

It depends on what I teach them. For example, if it is familiar to students, I will use English, and if it is so abstract, I have to speak Vietnamese to save time; so later in the lesson, I spoke Vietnamese. (My-SRI)

Thu expressed a similar concern for two reasons: the concept she intended to convey was too abstract to understand, and the students had a low level of proficiency.

There I used Vietnamese to ensure they understood; usually for something hard to understand, I use Vietnamese, and for elementary level and large classes, it is for sure. (Thu-SRI)

\section{The Limited Capacity of Peer Input}

The six teachers construed different meanings for peer input, but most of them presented a general view that this type of input has a limited capacity to promote learning. Table 4 shows the aspects of peer input conceived by the teachers. It reveals that they all thought that students can benefit from peers in learning vocabulary, but this depends on the proficiency levels of students. Most were concerned about erroneous learning due to students' lack of accuracy in using English. 


\section{Table 4}

Conceptions of Peer Input Across Six Teachers

\begin{tabular}{|l|c|c|c|c|c|}
\hline Teachers & $\begin{array}{c}\text { Erroneous } \\
\text { learning }\end{array}$ & $\begin{array}{c}\text { Idea } \\
\text { learning }\end{array}$ & $\begin{array}{c}\text { Vocabulary } \\
\text { learning }\end{array}$ & $\begin{array}{c}\text { Level of } \\
\text { proficiency }\end{array}$ & L1 use \\
\hline Kim & + & & + & + & \\
\hline Hoa & + & & + & + & \\
\hline My & + & + & + & & \\
\hline Phuc & + & & + & + & + \\
\hline Thu & + & + & + & + & \\
\hline Sinh & -- & + & + & -- & \\
\hline
\end{tabular}

For example, Kim's overriding conception was that mistakes from peers could harm learning. She only acknowledged the capacity of peer input under certain conditions, and it was quite dependent upon the learners' language ability. She explained that the language proficiency level of students played a role in influencing mutual learning. If the students' language ability was "ok," they "would still pick up the language, such as new words or structures that their friends use and that they have never thought out" (Kim-SRI). Thu, a less experienced teacher, expressed a similar view that the value of students' input lies in the opportunity to benefit from peer ideas or information rather than language:

Usually the input is mainly the idea they can learn from each other, so before writing or speaking I would ask them to discuss. For the language or accuracy of structures, I am not sure students would benefit from each other, because their levels are just the same. (Thu-SRI)

This way of viewing peer input differs from that of Sinh. This youngest teacher believed that peer input could support mutual learning:

...The input from students, when they come to talk to each other, would be easier for them to understand because their levels might be relatively similar. Therefore, it is more comfortable for them, I think, to listen to their classmates than to the teacher, the input from their classmates would be retained longer, and it is not certain that they would copy the mistakes from each other. I think they can realize what is wrong and what is right. (Sinh-SRI)

\section{Discussion}

The study generally showed that the teachers initially shared an overall conception of input from a synthetic or structuralist view of language. Accordingly, they all had an orientation to interpret input as the pre-determined divisible linguistic items to be taught for learning and mastery.

This conception influenced their interpretation of the SLA concept of comprehensible input. The notion was accommodated by the teachers converging various forms of input such as texts, teacher talk, or audiotapes to promote the learning and mastery of particular pre-determined linguistic elements. They still saw input, even in these forms, as ways of reinforcing or exposing students to the targeted items. Their conception of language input, in Saleemi's (1989) view, reflects the underpinning product-oriented view of language, which they largely experienced in their training.

Teacher use of English as input was thought to be useful for promoting exposure to English in the classroom, but the teachers limited it to certain pedagogical purposes relevant to teaching 
the target language. This limitation was found to have links with a combination of factors both contextual and experiential, such as the teachers' concern for students' comprehension if English was used at all time, students' limited level of English proficiency, and time pressures to complete lessons. This finding backs up the fact that teachers often perceive the benefits of target language use in the foreign language classroom to be restricted (Bateman, 2008; Macaro, 1997; Turnbull \& Arnett, 2002).

It appeared that multiple factors mediated the teachers' decisions to speak English in the classroom, but the learners' level seemed to be the most important factor. The perception of teacher input as restricted to pedagogical purposes also appeared to reveal that the teachers rarely saw their English use as an opportunity for communicating to students in an authentic sense. In this way, the institutional goal, which was to teach a foreign language and teach it accurately, clearly contributed to this restricted view (Seedhouse, 2005).

The students' level of proficiency also played an important role in the teachers' thinking about learning from peers. The more experienced teachers saw the benefits of peer input as dependent upon the students' levels of proficiency. They showed concern for grammatical and phonological accuracy and especially the incorporation of L1 in the input. This perception reflects not only a product-oriented view of teaching, but also the experiential beliefs established from their years of teaching General English to university students, whose proficiency levels are generally low (Nam, 2008; Thanh Ha, 2008).

Teachers' conceptions of language input as described above apparently reflected their response to the principle of generating extensive, rich, and comprehensible input. Among the teachers, only two brought into the classroom further input resources in form of written texts and audio. Even when this incorporation occurred, it was done with the purpose of promoting the recurrence of intended language items for learning and mastery or further introducing language items to students. With respect to making input comprehensible to students, the teachers attempted to incorporate redundancy in their speech in that they repeated a structure or form several times, explained new words by using miming, pictures, or paraphrases, or made language items salient in a written text for students to notice and learn. In general, the teachers' shared conception of language input reflects their synthetic view of language, conditioned by both their beliefs and the context in which they work. These observations of teachers interpreting concepts in their individual ways illustrates that a socially-situated constructivist perspective aligns well with attempts to understand why teachers, given an opportunity to learn, decide to use or reject useful skills, methods, and concepts (Berliner, 2005).

\section{Conclusion}

If TBLT, or any new approach for that matter, is to be successful, teacher developers need to understand the complexity of teacher's conceptions about teaching and learning, and especially about language itself. This study provides evidence, with particular relevance to the notion of language input, of this complexity. It also details the particular and immediate factors that teachers identified in their contexts as constraining their implementation of tasks and activities that would promote richer input. By understanding the complexity of teachers' thinking and both the immediate teaching context and the wider socio-cultural context, teacher developers may be better placed to respond to Berliner's (2005) call for the need to understand why teachers, given an opportunity to learn, decide to use or reject useful skills, methods, and concepts. 


\section{Biodata}

Nguyen Van Loi is a lecturer at the English Department, School of Education, Can Tho University, Vietnam. Currently he is completing his Ph.D study in education at the University of Waikato, New Zealand. His research areas include teacher cognition, SLA and teacher education.

Margaret Franken is a senior lecturer in the University of Waikato's Faculty of Education, but has international experience of working in China, Vietnam, and the Pacific. She has published mainly in the area of second language teacher education and more recently also in computer assisted language learning.

\section{References}

Bateman, B. E. (2008). Student teachers' attitudes and beliefs about using the target language in the classroom. Foreign Language Annals, 41 (1), 11-28. http://dx.doi.org/10.1111/j.1944-9720.2008.tb03277.x

Berliner, D. C. (2005). The place of process-product research in developing the agenda for research on teacher thinking. In P. M. Denicolo \& M. Kompf (Eds.), Teacher thinking and professional action (pp. 3-15). London, England: Routledge.

Borg, S. (2003). Teacher cognition in language teaching: A review of research on what language teachers think, know, believe, and do. Language Teaching, 36(2), 81-109. http://dx.doi.org/10.1017/S0261444803001903

Borg, S. (2006). Teacher cognition and language education: Research and practice. London, England: Continuum.

Canh, L. V. (2000). Language and Vietnamese pedagogical contexts. In J. Shaw, D. Lubeska, \& M. Noullet (Eds.), Language and development: Partnership and interaction (pp.73-79). Bangkok, Thailand: Asian Institute of Technology.

Canh, L. V. (2008). Teachers' beliefs about curricular innovation in Vietnam: A preliminary study. In Y. H. Choi \& B. Spolsky (Eds.), ELT curriculum innovation and implementation in Asia (pp. 191-215). Seoul, South Korea: Asia TEFL.

Carroll, S. E. (1999). Putting 'input' in its proper place. Second Language Research, 15(4), 337. http://dx.doi.org/10.1191/026765899674928444

Chaudron, C. (1985). Intake: On models and methods for discovering learners' processing input. Studies in Second Language Acquisition, 7, 1-14. http://dx.doi.org/10.1017/S027226310000512X

Denzin, N. K. (1988). Triangulation. In J. P. Keeves (Ed.), Educational research, methodology, and measurement: An international handbook (pp. 511-513). Oxford, England: Pergamon Press.

Doughty, C. J., \& Long, M. H. (2003). Optimal psycholinguistic environments for distance foreign language learning. Language Learning and Technology, 7(3). http://lt.msu.edu/vol7num3/doughty/default.html

Ellis, R. (1985). Teacher-pupil interaction in second language development. In S. M. Gass \& C. G. Madden (Eds), Input in second language acquisition (pp. 69-85). Rowley, MA: Newbury House.

Ellis, R. (2003). Task-based language learning. Oxford, England: Oxford University Press.

Ellis, R. (2005). Principles of instructed language learning. Asian EFL Journal, 7(3). Retrieved from http://www.asian-efl-journal.com/September_05_re.php

Entwistle, N., Skinner, D., Entwistle, D., \& Orr, S. (2000). Conceptions and beliefs about good teaching: An integration of contrasting research areas. Higher Education Research \& Development, 19(1), 5-26. http://dx.doi.org/10.1080/07294360050020444 
Freeman, D., \& Johnson, K. E. (2005). Response to Tarone and Allwright. In D. J. Tedick (Ed.), Second language teacher education: International perspectives (pp. 25-32). New Jersey: Lawrence Erlbaum Associates.

Harley, B. (1998). The role of focus-on-form tasks in prompting child L2 acquisition. In C. Doughty \& J. Williams (Eds.), Focus on form in second language acquisition (pp.156174). Cambridge, England: Cambridge University Press.

Hedge, T. (2000). Teaching and learning in the language classroom. Oxford, England: Oxford University Press.

Krashen, S. (1985). The input hypothesis: Issues and implications. London, England: Longman. Lightbown, P. M. (2000). Anniversary article: Classroom SLA research and second language teaching. Applied Linguistics, 21(4), 431-462. http://dx.doi.org/10.1093/applin/21.4.431

Littlewood, W. (2007). Communicative and task-based language teaching in East Asian classrooms. Language Teaching, 40, 243-249. http://dx.doi.org/10.1017/S0261444807004363

Long, M. H. (1981). Input, interaction, and second-language acquisition. Annals of the New York Academy of Sciences, 379(1), 259-278. http://dx.doi.org/10.1111/j.17496632.1981.tb42014.x

Long, M. H., \& Crookes, G. (1992). Three approaches to task-based syllabus design. TESOL Quarterly, 26(1), 27-56.

Macaro, E. (1997). Target language, collaborative learning and autonomy. Clevedon, England: Multilingual Matters.

Mangubhai, F. (2006). What do we know about learning and teaching second languages: Implications for teaching. Asian EFL Journal, 8(3). Retrieved from http://asian-efljournal.com/Sept_06_fm.php

Nam, D. H. (2008, December 08). Vi sao sinh vien ra truong khong noi duoc tieng Anh? [Why can't graduates speak English?] Tuoi Tre, from http://www.tuoitre.com.vn/Tianyon/Index.aspx?ArticleID=291136\&ChannelID=13

Pham, H. H. (2005). Readers respond: University English classrooms in Vietnam. ELT Journal, 59(4), 336-338. http://dx.doi.org/10.1093/elt/cci063

Saleemi, A. P. (1989). Inputs for L2 acquisition. IRAL - International Review of Applied Linguistics in Language Teaching, 27(3), 173-191. http://dx.doi.org/10.1515/iral.1989.27.3.173

Seedhouse, P. (2005). Conversation analysis as research methodology. In K. Richards \& P. Seedhouse (Eds.), Applying conversation analysis (pp. 251-266). Basingstoke, England: Palgrave Macmillan.

Shehadeh, A. (2005). Task-based language learning and teaching: Theories and applications. In C. Edwards \& J. Willis (Eds.), Teachers exploring tasks in English language teaching (pp.13-30). New York, NY: Palgrave Macmillan.

Swan, M. (2005). Legislation by hypothesis: The case of task-based instruction. Applied Linguistics, 26(3), 376-401. http://dx.doi.org/10.1093/applin/ami013

Tarone, E., \& Allwright, D. (2005). Second language teacher learning and student second language learning: Shaping the knowledge base. In D. J. Tedick (Ed.), Second language teacher education: International perspectives (pp. 5-24). New Jersey: Lawrence Erlbaum Associates.

Thanh Ha. (2008, December 6). Giảng dạy tiếng Anh trong các trường ĐH: kém vì thiếu chuẩn [Teaching English in universities: Poor due to lack of standards]. Tuoi Tre Online. Retrieved from http://translate.google.co.nz/translate?hl=en\&sl=vi\&u=http://tuoitre.vn/Giaoduc/291254/Giang-day-tieng-Anh-trong-cac-truong-DH-kem-vi-thieu-chuan.html 
Trinh, Q. L. (2005). Stimulating learner autonomy in English language education: A curriculum innovation study in a Vietnamese context (Doctoral dissertation, Universiteit van Amsterdam, Amsterdam, Netherlands).

Turnbull, M., \& Arnett, K. (2002). Teachers' uses of the target and first languages in second and foreign language classrooms. Annual Review of Applied Linguistics, 22(1), 204-218. http://dx.doi.org/10.1017/S0267190502000119

Wesche, M. B. (1994). Input and interaction in second language acquisition. In C. Gallaway \& B. J. Richards (Eds.), Input and interaction in language acquisition (pp. 219-249). Cambridge, England: Cambridge University Press.

\section{Appendix A}

\section{Researcher's Field Notes from the Workshop on Input}

I began by talking about some studies related to this condition, focusing on the importance of input in language acquisition. I then clarified the input hypothesis and its implications before talking about some ways to make language input richer and comprehensible to learners. Tasks to promote language input were introduced to them [the teacher participants] in the handouts as samples. An emphasis is made on the idea of being creative and flexible in techniques, and not following what was proposed. The session ended with a demonstration of a task where I dictated a short text about language input, and the teachers had to take notes and reconstruct the text in a group. At the end of the illustration, I asked them to give comments. The purpose of this illustration was to enable them to think about the concept of revisiting input as one of the ways to optimize the acquisition of language.

\section{Initial interview prompts:}

\section{Interview Prompts Used on Three Occasions}

1. What do you think is an effective English lesson?

2. Would you describe your classroom lessons as effective? Why?

3. What conditions are needed for effective second language learning and acquisition? Why?

4. What do you think about input? Is it important?

5. In what ways?

6. What is good input?

7. How did you address it in your lessons?

\section{Lesson plan interview prompts:}

1. Can you tell me about your plan for this lesson?

2. What do you think about the input in the unit?

3. What do you plan to do with input?

4. Do you plan to incorporate more input? How?

\section{Stimulated recall interview prompts:}

1. What technique/task were you using for input here?

2. What were you thinking when you gave this activity?

3. What were you aiming at in this task/activity?

4. What were you noticing about the students?

5. How was the students' response?

6. What would you say about the students' reaction to the activity?

7. What would you say about the task/activity?

8. I saw you teach this grammar point/vocabulary. Why was that?

9. What were you thinking at that time?

10. Were you thinking of any alternative actions or strategies at that time?

11. How did you feel about the activity/task?

12. What is your general comment about this lesson? Why? 


\section{Appendix B}

\section{Lesson Plans for Language Input}

Table B

Lesson Plans for Language Input

\begin{tabular}{|c|c|c|c|c|}
\hline Teachers & $\begin{array}{l}\text { Lessons \& } \\
\text { Levels }\end{array}$ & Time & Objectives & Lesson procedure \\
\hline Kim & $\begin{array}{l}\text { Unit 11: A } \\
\text { day in my } \\
\text { life (Level } \\
\text { 2) }\end{array}$ & $\begin{array}{l}180 \\
\text { min. }\end{array}$ & $\begin{array}{l}\text { - Read and comprehend } \\
\text { someone's working day. } \\
\text { - Listen and comprehend } \\
\text { main points of speakers' talks } \\
\text { in forms of monologue and } \\
\text { dialogue. } \\
\text { - Talk to their friend about } \\
\text { their typical day. } \\
\text { - Write a paragraph about a } \\
\text { typical day. } \\
\text { - Use simple present tense, } \\
\text { adverbs of frequency, } \\
\text { prepositions of time, and } \\
\text { vocabulary on people's jobs } \\
\text { and daily activities in their } \\
\text { description of a typical day. }\end{array}$ & $\begin{array}{l}\text { - Read the passage My working } \\
\text { day and complete exercises 1-3 } \\
\text { and a chart. } \\
\text { - Work in pairs and groups to } \\
\text { ask and answer about their } \\
\text { typical working day, using the } \\
\text { language they have just picked } \\
\text { up. } \\
\text { - Present their talk and listen to } \\
\text { each other. Report what has } \\
\text { been said. } \\
\text { - Listen to texts in the book. } \\
\text { - Read further texts (external } \\
\text { source). } \\
\text { - Listen to further texts (external } \\
\text { source). } \\
\text { - Write about someone's typical } \\
\text { day. }\end{array}$ \\
\hline Hoa & $\begin{array}{l}\text { Unit 21: } \\
\text { Mystery } \\
\text { (Level 3) }\end{array}$ & $\begin{array}{l}150 \\
\min .\end{array}$ & $\begin{array}{l}\text { - Make negative sentences in } \\
\text { the simple past tense. } \\
\text { - Make Wh-questions in the } \\
\text { simple past tense. } \\
\text { - Notice the unstressed sound } \\
\text { of the auxiliary did. } \\
\text { - Use the simple past tense to } \\
\text { talk/write a short } \\
\text { autobiography. }\end{array}$ & $\begin{array}{l}\text { - Look at the picture of Agatha } \\
\text { Christie and listen to the teacher } \\
\text { briefly talking about Agatha. } \\
\text { - Ask questions about her. Use } \\
\text { Wh-questions. } \\
\text { - Read the text about her, and } \\
\text { answer questions in the book. } \\
\text { - Work in pairs or individually } \\
\text { to underline the simple past } \\
\text { verbs in the text. } \\
\text { - Repeat the underlined verbs in } \\
\text { chorus after the teacher. } \\
\text { - Work in pairs; one reads out } \\
\text { loud and one listens. } \\
\text { - T reminds S of the simple past } \\
\text { tense form. } \\
\text { - Give examples of the tense in } \\
\text { different forms orally. } \\
\text { - Do the exercises in the book } \\
\text { about the tense. } \\
\text { - Listen to the tape for the } \\
\text { pronunciation of the -ed ending } \\
\text { and repeat in chorus after the } \\
\text { tape. } \\
\text { - Do the writing and speaking } \\
\text { exercises } 1,2 \text {, and } 3 \text { in the } \\
\text { book. }\end{array}$ \\
\hline
\end{tabular}




\begin{tabular}{|c|c|c|c|c|}
\hline Teachers & $\begin{array}{l}\text { Lessons \& } \\
\text { Levels }\end{array}$ & Time & Objectives & Lesson procedure \\
\hline Thu & $\begin{array}{l}\text { Unit 24: } \\
\text { I'm going } \\
\text { to save } \\
\text { money } \\
\text { (Level 3) }\end{array}$ & $\begin{array}{l}270 \\
\min .\end{array}$ & $\begin{array}{l}\text { - Read and listen for specific } \\
\text { information. } \\
\text { - Talk about what they are } \\
\text { going to do on the nearest } \\
\text { weekend. } \\
\text { - Write sentences and then a } \\
\text { paragraph about their } \\
\text { weekend plan. } \\
\text { - Present their solutions for } \\
\text { problems given. } \\
\text { - Write about their resolutions } \\
\text { for the coming semester. }\end{array}$ & $\begin{array}{l}\text { - Guessing game } \\
\text { - T presents I'm going to. } \\
\text { - T pre-teaches vocabulary. } \\
\text { - Read the text in the book. } \\
\text { - Combine sentences using } \\
\text { because. } \\
\text { - Listening (activities } 3 \& 4 / \mathrm{p} \text {. } \\
\text { 56) } \\
\text { - Say what you are going to do } \\
\text { this weekend through a drill. } \\
\text { - Do homework: write } \\
\text { sentences about your weekend } \\
\text { plans. } \\
\text { - Work in pairs and discuss } \\
\text { solutions to given problems. } \\
\text { - Present your solutions to the } \\
\text { whole class. }\end{array}$ \\
\hline Phuc & $\begin{array}{l}\text { Unit 13: } \\
\text { Can you } \\
\text { swim? } \\
\text { (Level 2) }\end{array}$ & $\begin{array}{l}90 \\
\min .\end{array}$ & (Unavailable) & $\begin{array}{l}\text { - Teacher teaches vocabulary. } \\
\text { - Read the text and work out the } \\
\text { form of can and can't. } \\
\text { - Listen to a short oral } \\
\text { description by the teacher and } \\
\text { answer some questions. } \\
\text { - Listen to an interview with a } \\
\text { man applying for a job and tick } \\
\text { the abilities of the applicant. } \\
\text { - Role-play the interview. } \\
\text { - Interview a friend based on the } \\
\text { checklist in the book about the } \\
\text { friend's abilities. } \\
\text { - Listen and match sentences. } \\
\text { - Teacher explains the use of So } \\
\text { can I and Neither can I. } \\
\text { - Role play the conversation } \\
\text { with your friend talking about } \\
\text { your real abilities. } \\
\text { - Teacher corrects any mistakes. }\end{array}$ \\
\hline My & $\begin{array}{l}\text { Unit 3: } \\
\text { Personal } \\
\text { information } \\
\text { (Level 1) }\end{array}$ & $\begin{array}{l}50 \\
\min .\end{array}$ & $\begin{array}{l}\text { - Ask and answer questions } \\
\text { on personal information. }\end{array}$ & $\begin{array}{l}\text { - Brainstorm vocabulary on } \\
\text { personal information. } \\
\text { - Do prediction exercise on } \\
\text { page } 6 \text { of the book. } \\
\text { - Listen and check answers. } \\
\text { - Read the conversation in the } \\
\text { book and fill in the given chart. } \\
\text { - Play the game 'Who is He?' } \\
\text { - Work in pairs; ask and answer } \\
\text { questions about the person in } \\
\text { the photos (handout given). } \\
\text { - Role-play the conversations. }\end{array}$ \\
\hline
\end{tabular}




\begin{tabular}{|c|c|c|c|c|}
\hline Teachers & $\begin{array}{l}\text { Lessons \& } \\
\text { Levels }\end{array}$ & Time & Objectives & Lesson procedure \\
\hline Sinh & $\begin{array}{l}\text { Unit 11: A } \\
\text { day in my } \\
\text { life (Level } \\
\text { 2) }\end{array}$ & $\begin{array}{l}90 \\
\min .\end{array}$ & $\begin{array}{l}\text { - Use words/phrases about } \\
\text { daily activities. } \\
\text { - Use adverbs of frequency } \\
\text { and prepositions of time. } \\
\text { - Scan information in a } \\
\text { reading text. } \\
\text { - Ask/answer Yes-No and Wh- } \\
\text { questions in the present } \\
\text { simple tense. }\end{array}$ & $\begin{array}{l}\text { - Brainstorm vocabulary about } \\
\text { daily activities (individually, } \\
\text { groups of 2, groups of } 6 \text { ). } \\
\text { - Predict true or false for the } \\
\text { statements given. } \\
\text { - Read the text in the book to } \\
\text { check. } \\
\text { - Fill in the activities with the } \\
\text { time points given in the chart. } \\
\text { - Present adverbs of frequency } \\
\text { and prepositions of time. } \\
\text {-Practice the rules with drill cues. } \\
\text { - Role-play being a journalist } \\
\text { asking Tanya about her working } \\
\text { day. Try to include adverbs of } \\
\text { frequency in your answers. }\end{array}$ \\
\hline
\end{tabular}

